\title{
INTERNAL RADIATION DOSE ASSESSMENT USING IRDA SOFTWARE FOR BANGLADESHI SUBJECTS DUE TO INGESTION OF CO-60
}

\author{
A.H.M. R. Quddus', M. Moksed Ali², M. M. A. Zaman $^{3}$ and A.S. Mollah ${ }^{4}$ \\ ${ }^{1}$ Department of Physics, National University, Gazipur, Bangladesh \\ ${ }^{2}$ Army Education Corps, Bangladesh Army \\ ${ }^{3}$ Department of Physics, Jahangirnagar University \\ ${ }^{4}$ International Affairs Division, Bangladesh Atomic Energy Commission, Dhaka \\ e-mail: rqbd@yahoo.com, mollah_as@yahoo.com
}

\begin{abstract}
Retention, absorbed dose, committed equivalent dose and committed effective doses have been assessed due to acute ingestion of $1 \mathrm{~Bq}$ of ${ }^{60} \mathrm{Co}$ in human body. Calculations are done using "Internal Radiation Dose Assessment (IRDA)" software which has been developed based on the biokinetic model. Due to ingestion maximum radiation dose is deposited in the gastro intestinal (GI) tract, assumed to consist of four tissue compartments, e.g. stomach (ST), small intestine (SI), upper large intestine (ULI) and lower large intestine (LLI). In this work actual tissue masses of GI Tract of Bangladeshi people have been considered to calculate the above mentioned quantities for different age groups, such as $1 \mathrm{yr}, 10 \mathrm{yrs}$ and adult (female and male). One hour after the ingestion, the retention and absorbed dose show the trend ST > SI > ULI > LLI. Regarding tissue compartments the variation of the committed equivalent dose pattern is LLI $>$ ULI $>$ ST $>$ SI for the radionuclide. The variation of absorbed dose, committed equivalent dose and committed effective dose with respect to age follow the pattern: $1 \mathrm{yr}>10 \mathrm{yrs}>$ adult female $>$ adult male. The highest committed effective dose for ingestion of $1 \mathrm{~Bq}$ of the radionuclide under the study is found in the GI tract of $1 \mathrm{yr}$ old child. This value is 6.56 x $10^{-6} \mathrm{mSv}$. For other age groups these values are slightly less.
\end{abstract}

Keywords: Radiation dose assessment, IRDA, Biokinetic model.

\section{INTRODUCTION}

Intakes of radionuclides in the body can occur via a number of routes. Four main routes to work in internal exposure are: inhalation, ingestion, dermal absorption and direct injection (or through a wound). Intakes by ingestion may occur, as absorption through the intact skin for some radionuclides. Radionuclides when ingested through food and drink, are absorbed principally from the small intestine, facilitated by its variable mass and immense surface area of about $200 \mathrm{~m}^{2}[1,2]$. If the material is not absorbable, it traverses the gastrointestinal tract and is excreted in the feaces. For absorbable materials, a significant fraction is absorbed into the blood and lymphatic system. The actual degree of absorption may depend on the metabolism and nutrition of the individual as well as the chemical compound in which the radionuclide is ingested. A significant contribution in this regard is due to Harrison [3] who reviewed the anatomical, physiological and radiobiological aspects of radionuclide ingestion.

Now how much radionuclides can be absorbed in a year without causing much of hazard? In this respect ICRP recommends a limit on effective doses both for occupational workers and general public. The occupational and public exposure of any worker shall be so controlled that the limits be not exceeded.

Because of increasing application of nuclear industries and nuclear medicine in these days it is mandatory to assess and control both external and internal doses to occupational workers and evaluate and examine the trend of radiation exposure to members of the public. For this purpose employment of appropriately designed monitoring methods should be made. Together with it, it will be worth to know the values of doses per unit intake, which, might be transferred from environmental media into foodstuffs and subsequently ingested by members of the public. The present work has been planned in this regard: to say more specifically for calculation of internal radiation due to acute intake of ${ }^{60} \mathrm{Co}$ radioisotope through ingestion by radiation workers/public considering biological aspects of Bangladeshi people by using indigenously developed IRDA [7] software. Additionally it has been used for the calculation of equivalent 
dose. In all these works the software has been used. For intakes by ingestion, the GI tract model [4] is used to calculate the dose coefficients. It describes movement through four regions of the GI tract with parameter values for assessing the radiation dose to walls of the stomach and gut and the fractional uptake of elements into the blood, given as $f_{1}$ values $\left(f_{1}\right.$, the fractional uptake from the GI tract, is the gut transfer factor). The current biokinetic models of the ICRP for systemic activity [5, 6] were used for calculating dose coefficients for intakes by inhalation and ingestion.

\section{MATHEMATICAL FORMULATION}

The function describing uptake and retention of a radionuclide in a body tissue following its ingestion is described considering an organ to consist of a number of separate compartments. Loss of radionuclide from one compartment is taken to be governed by the first order kinetics. Therefore the retention of an element in any organ or tissue will usually be described by either single exponential term or the sum of a number of exponential terms [4]

The rate constants $\left(\lambda_{B}\right)$ for the different compartments in the gastrointestinal tract system and the radioactive decay constant $\left(\lambda_{R}\right)$ of the radionuclide determine the rate of translocation to the body fluids after the radionuclide has been ingested. For the present purpose the GI tract is represented by four sections (Fig.1); and each of these sections is considered as a single compartment.

The translocation from one compartment to the next is expressed by first order kinematics; and thus $q(t)$, the activity of ingested radionuclide in a compartment at time $\mathrm{t}$ is described by the following equations [4]

$$
\begin{aligned}
& \frac{d}{d q} q_{S T}(t)=-\lambda_{S T} q_{S T}(t)-\lambda_{R} q_{S T}(t)+\dot{I}(t) \\
& \frac{d}{d q} q_{S I}(t)=-\lambda_{S I} q_{S I}(t)-\lambda_{R} q_{S I}(t)-\lambda_{B} q_{S I}(t)+\lambda_{S T} q_{S T}(t) \\
& \frac{d}{d q} q_{U L I}(t)=-\lambda_{U L I} q_{U L I}(t)-\lambda_{R} q_{U L I}(t)+\lambda_{S I} q_{S I}(t) \\
& \frac{d}{d q} q_{L L I}(t)=-\lambda_{L L I} q_{L L I}(t)-\lambda_{R} q_{L L I}(t)+\lambda_{U L I} q_{U L I}(t)
\end{aligned}
$$

where, $\lambda_{R}$ is the radioactive decay constant of the radioactive nuclide, $\lambda_{S T}, \lambda_{S I}, \lambda_{U L I}, \lambda_{L L I}$ are the rate constants for loss of material from stomach, small intestine, upper large intestine and lower large intestine respectively, $I(t)$ is the rate of intake of activity from outside the system into stomach at time t. $\lambda_{B} q_{S I}(t)$ is the rate of transfer of activity to body fluids from the small intestine, which is assumed to be 
the only site of absorption from the GI tract to body fluids, and $I(t)$ is the rate of ingestion of activity of the radionuclide at time $t$. The value of $\lambda_{B}$ can be estimated from $f_{1}$, the fraction of a stable element reaching the body fluids following ingestion; and $\lambda_{B}$ is given by:

$$
\lambda_{B}=\frac{f_{1} \lambda_{S I}}{1-f_{1}}
$$

For $f_{1}=1$ it is assumed that the radionuclides pass directly from small intestine to body fluids and does not pass through other sections of the gastrointestinal tract. $\dot{I}(\mathrm{t})$ may be set equal to zero for all radionuclides considering time $t$ to be zero at the time of single instantaneous intake, $q_{1}(0)$ may be set equal to zero for all $i$ from 2 to $n$, i.e. for all other compartments of the chain. Under these boundary conditions Skrable et al. [8] have shown that

$$
q_{i}(t)=\left[\left(\prod_{k=1}^{i=-1} \lambda_{(k, k+1)}\right) \sum_{k=1}^{i}\left(\frac{q_{1}(0) e^{-\lambda_{k} t}}{\prod_{p=1, p \neq k}^{i} \Pi\left(\lambda_{p}-\lambda_{k}\right)}\right)\right]
$$

Where,

$$
\begin{aligned}
& \prod_{i=m}^{n} a_{i}=a_{m} \times a_{m+1} \times \ldots . a_{n} \text { if } \mathrm{n} \geq \mathrm{m} \\
& \left.\prod_{i=m}^{n}=1 \text { if } \mathrm{m}\right\rangle \mathrm{n}
\end{aligned}
$$

$\mathrm{q}_{\mathrm{i}}(\mathrm{t})$ is the activity of a radionuclide in compartment $\mathrm{i}$ at time $\mathrm{t}$. If $q_{1}(0)$ is considered to be equal to $\mathrm{Q}$, the amount of activity initially introduced. $q_{1}(t)=q_{s t}(t)$ is the activity in the transfer compartment stomach (ST) at any time t, $q_{2}(t)=q_{S I}(t)$ is the activity in the tissue compartment small intestine (SI), $q_{3}(t)=q_{U L I}(t)$ is the activity in the tissue compartment upper large intestine (ULI), $q_{4}(t)=q_{L L I}(t)$ is the activity in the tissue compartment lower large intestine (LLI).

Then the solution of these equations for retention can be obtained as [8]:

$$
\begin{aligned}
& q_{S T}(t)=Q e^{-\left(\lambda_{S T}+\lambda_{R}\right) t} \\
& q_{S I}(t)=\frac{Q \times \lambda_{S T}}{\left(\lambda_{S T}-\lambda_{S I}-\lambda_{B}\right)} \times\left\{e^{-\left(\lambda_{S I}+\lambda_{B}+\lambda_{R}\right) t}-e^{-\left(\lambda_{S T}+\lambda_{R}\right) t}\right\}
\end{aligned}
$$




$$
q_{U L I}(t)=\frac{Q \times \lambda_{S T} \times \lambda_{S I}}{\left(\lambda_{S T}-\lambda_{S I}-\lambda_{B}\right)}\left[\begin{array}{l}
\frac{e^{-\left(\lambda_{S T}+\lambda_{R}\right) t}}{\left(\lambda_{S I}+\lambda_{B}-\lambda_{S T}\right)\left(\lambda_{U L I}-\lambda_{S T}\right)}+\frac{e^{-\left(\lambda_{S I}+\lambda_{R}+\lambda_{B}\right) t}}{\left(\lambda_{S T}-\lambda_{B}-\lambda_{S I}\right)\left(\lambda_{U L I}-\lambda_{S I}-\lambda_{B}\right)}+ \\
\frac{e^{-\left(\lambda_{U L I}+\lambda_{R}\right) t}}{\left(\lambda_{S T}-\lambda_{U L I}\right)\left(\lambda_{S I}+\lambda_{B}-\lambda_{U L I}\right)}
\end{array}\right]
$$

$$
q_{L L I}(t)=\frac{Q \times \lambda_{S T} \times \lambda_{S I} \times \lambda_{U L I}}{\left(\lambda_{S T}-\lambda_{S I}-\lambda_{B}\right)}\left[\begin{array}{l}
\frac{e^{-\left(\lambda_{S T}+\lambda_{R}\right) t}}{\left(\lambda_{S I}+\lambda_{B}-\lambda_{S T}\right)\left(\lambda_{U L I}-\lambda_{S T}\right)\left(\lambda_{L L I}-\lambda_{S T}\right)}+\frac{e^{-\left(\lambda_{S I}+\lambda_{R}+\lambda_{B}\right) t}}{\left(\lambda_{S T}-\lambda_{B}-\lambda_{S I}\right)\left(\lambda_{U L I}-\lambda_{S I}-\lambda_{B}\right)\left(\lambda_{L L I}-\lambda_{S I}-\lambda_{B}\right)} \\
\frac{e^{-\left(\lambda_{L L}+\lambda_{R}\right) t}}{\left(\lambda_{S T}-\lambda_{L L I}\right)\left(\lambda_{S I}+\lambda_{B}-\lambda_{L L I}\right)\left(\lambda_{L L I}-\lambda_{U L}\right)}+\frac{e^{-\left(\lambda_{U L L}+\lambda_{R}\right) t}}{\left(\lambda_{S T}-\lambda_{U L}\right)\left(\lambda_{S I}+\lambda_{B}-\lambda_{U L}\right)\left(\lambda_{L L I}-\lambda_{U L I}\right)}
\end{array}\right]
$$

The dose absorbed per unit time to a particular organ or tissue after a certain time of acute intake is now given by

$$
\mathrm{D}(\mathrm{t})==1.6 \times 10^{-10} \sum_{s}\left[q_{S}(t) \sum \operatorname{SEE}(T \leftarrow S)_{i}\right]_{j} \text { in } \mathrm{mSv}
$$

Here, $q_{S}(t)$ is the retention at particular compartment $\mathrm{S}$, after a certain time of a particular radionuclide $\mathrm{j}$, from the acute intake. Summation in $\mathrm{S}$ is due to irradiation of target organ $\mathrm{T}$ by radiations arising in several different sources $\mathrm{S}$.

SEE $(T \leftarrow S)_{\mathrm{i}}$ is the specific effective energy from radiation of type $\mathrm{i}$ originating in $\mathrm{S}$.

For a particular radionuclide $\mathrm{j}$, the term is given by

$$
\operatorname{SEE}(\mathrm{T} \leftarrow \mathrm{S})_{\mathrm{i}}=\frac{Y_{i} E_{i} A F(T \leftarrow S)_{i} Q_{i}}{M_{T}} \mathrm{MeV} \mathrm{kg}^{-1} \text { per transformation }
$$

Here, $\mathrm{E}_{\mathrm{i}}($ in $\mathrm{MeV}$ ) is the average, or unique energy of radiation $\mathrm{i}, \mathrm{AF}(\mathrm{T} \leftarrow S)$ is the average fraction of energy absorbed in $\mathrm{T}$ from radiation arising in $\mathrm{S}, \mathrm{Y}_{\mathrm{i}}$ is the yield of radiations of type i per transformation of radionuclide $\mathrm{j}, \mathrm{Q}_{\mathrm{i}}$ is the quality factor appropriate for radiation $\mathrm{i}$, and $\mathrm{M}_{\mathrm{T}}$ (in $\mathrm{g}$ ) is the mass of the target organ.

Total number of disintegration over a certain period is found by time integration of eq. 6, 7, 8 and 9 respectively for ST, SI, ULI and LLI. The approximate expressions for the number of transformations in the various organs of the gastrointestinal tract following ingestion of $1 \mathrm{~Bq}$ of activity are all given in ref. [4]

The committed dose equivalent $\mathrm{H}_{50, \mathrm{i}}$ for each type of radiation $\mathrm{i}$, in target organ $\mathrm{T}$ resulting from radionuclide $\mathrm{j}$ in source organ $\mathrm{S}$ is the product of the two factors. These are the total number of transformation of radionuclide $\mathrm{j}$ in $\mathrm{S}$ over whole life time after intake, and the energy absorbed per $\mathrm{g}$ in $\mathrm{T}$, suitably modified for quality factor, from radiation of type I per transformation of radionuclide $\mathrm{j}$ in $\mathrm{S}$, i.e., for each radiation of type i from radionuclide $j$. 


$$
\mathrm{H} 50(\mathrm{~T} \leftarrow \mathrm{S})_{\mathrm{i}}=\mathrm{U}_{\mathrm{S}} \times 1.6 \times 10^{-13} \times \mathrm{SEE}(\mathrm{T} \leftarrow \mathrm{S})_{\mathrm{i}} \mathrm{SV}
$$

Where $U_{s}$ is the number of transformation of $\mathrm{j}$ in $\mathrm{S}$ over 50 years following intake of the radionuclide;

$$
\mathrm{H} 50(\mathrm{~T} \leftarrow \mathrm{S})_{\mathrm{i}}=\mathrm{U}_{\mathrm{S}} \times 1.6 \times 10^{-10} \times \mathrm{SEE}(\mathrm{T} \leftarrow \mathrm{S})_{\mathrm{i}} \mathrm{mSv}
$$

And for all type of radiation emitted by radionuclide $\mathrm{j}$

$$
\mathrm{H} 50(\mathrm{~T} \leftarrow \mathrm{S})_{\mathrm{i}}=1.6 \times 10^{-10}\left[U_{s} \sum_{i} S E E(T \leftarrow S)_{i}\right]_{j} m S v
$$

Committed Effective Dose for the GI tract is the summation over the product of committed effective dose and tissue weighting factor.

$$
\mathrm{E}(\tau)=\sum_{t} H \times W_{t} \mathrm{mSv}
$$

where, $\mathrm{W}_{\mathrm{t}}$ is the tissue weighting factor.

\section{BIOKINETIC MODEL FOR COBALT-60}

The fraction of ${ }^{60} \mathrm{Co}$ reaching the body fluid following ingestion is 0.1 [9]. After the entry into the transfer compartment, $50 \%$ of the cobalt is rapidly excreted with a biological half-life of 0.5 day, $5 \%$ of it is taken up by the liver and $45 \%$ is uniformly distributed in all other tissues. Fractions of $0.6,0.2$ and 0.2 are assumed to be lost from the liver and other tissues, with biological half lives of 6,60 and 800 days respectively. For activity loss through excretion from systematic compartments, $86 \%$ is assumed to be lost to urine and $14 \%$ to faeces.

\section{RESULTS AND DISCUSSION}

In the present work calculations have been done by using IRDA [7] software for retention, cumulative activity, absorbed dose, equivalent dose and committed effective dose from acute intake of ${ }^{60} \mathrm{Co}$. Due to ingestion maximum radiation dose is deposited in the GI tract, which consists of four tissue compartments, e.g., ST, SI, ULI and LLI. Tissue masses of GI tract for Bangladeshi people have been considered to calculate the above mentioned quantities for different age groups such as $1 \mathrm{yr}, 10 \mathrm{yrs}$ and adult (female and male). The transfer of radionuclide from oral cavity to the stomach has been considered an instantaneous process which gives no retention in the entry route. For retention calculation the subject has been assumed to have taken $1 \mathrm{~Bq}$ of acute ingestion. Retention has been assessed at different compartments of GI tract of the subjects of age groups $1 \mathrm{yr}, 10 \mathrm{yrs}$ and adult both male and female after $0.5 \mathrm{hr}, 1 \mathrm{hr}, 2 \mathrm{hrs}, 4 \mathrm{hrs}, 8 \mathrm{hrs}, 12 \mathrm{hrs}, 24 \mathrm{hrs}$ and $48 \mathrm{hrs}$ of ingestion of $1 \mathrm{~Bq}$ of the radionuclide.

Retention-time graph for ${ }^{60} \mathrm{Co}$ (Fig.1) shows that excepting the tissue ST, the other three tissues are characterized by their tendency to rise initially and then subsequent falling. Stomach (ST), being the first tissue on the path of the intake of the radionuclide will be initially met by the radionuclide. This phenomenon will happen initially at the starting time. Later on the radionuclides will be excreted and hence its value will be decreased continuously. The excreted radionuclide will then appear in the next tissue, e.g. small intestine (SI). Hence after the lapse of this time, small intestine will show a growth, the peak appearing at around $2 \mathrm{hrs}$ after ingestion. Retention in the small intestine is the maximum at this time. The rise rate is quicker as can be observed easily from Fig.1. The amount of deposition is excreted in a longer duration of about $20 \mathrm{hrs}$ to $24 \mathrm{hrs}$ from initial intake time. 


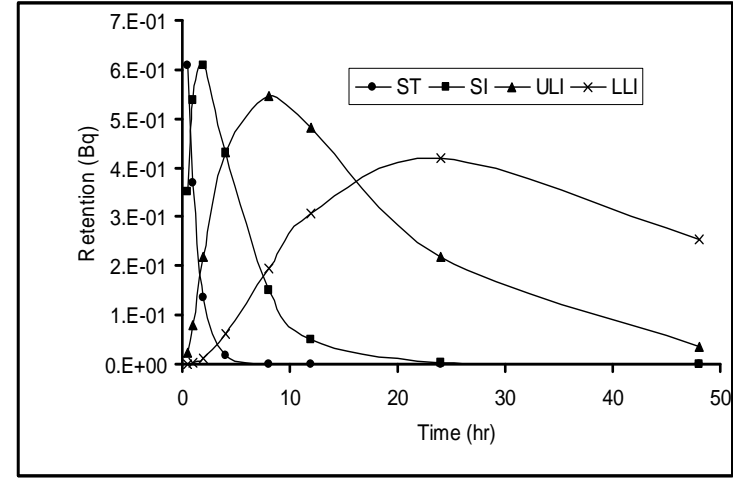

Fig. 1 Variation of retention with time for ${ }^{60} \mathrm{Co}$

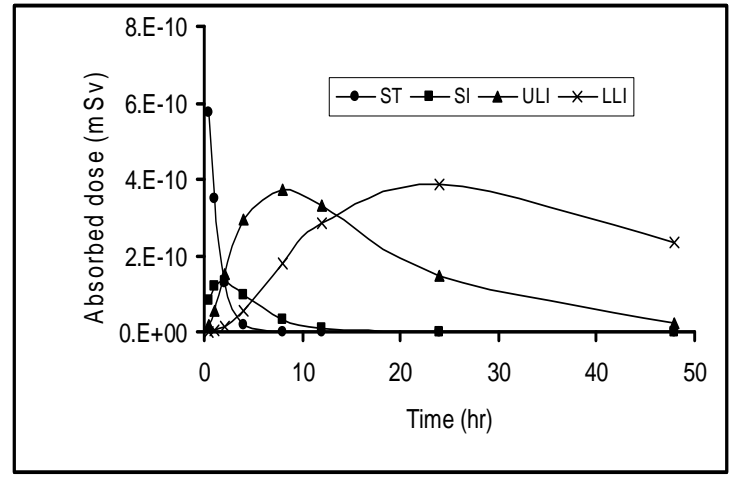

Fig. 2 Variation of absorbed dose due to ${ }^{60} \mathrm{Co}$ with time for $1 \mathrm{yr}$ old child

The excreted radionuclide is then deposited in the later tissue, ULI. The initial rise rate is $0.112 \mathrm{~Bq}$ per $\mathrm{hr}$ (between $0.5 \mathrm{hr}$ and $1 \mathrm{hr}$ of intake) and the maximum retention in the organ is $0.547 \mathrm{~Bq}$, which happens at around $8 \mathrm{hrs}$ after intake of the radionuclide. The retention value then continuously decreases and after an elapse of $48 \mathrm{hrs}$ it retains approximately $0.036 \mathrm{~Bq}$ in total. The falling rate is guided by an exponential function, which is similar for every individual radionuclide.

The last compartment is the LLI, where the excreted radionuclides from ULI are deposited. The curve corresponding to the growth in and decay from the LLI shows that the growth and decay rates for LLI are smaller than the previous ones. For this case the maximum rates are respectively 0.009 (between $12^{\text {th }} \mathrm{hr}$ and $24^{\text {th }} \mathrm{hr}$ of intake) and $0.007 \mathrm{~Bq}$ per hr (between $24^{\text {th }} \mathrm{hr}$ and $48^{\text {th }} \mathrm{hr}$ of intake).

As the radionuclide from the upper large intestine is excreted side by side it is also deposited in the LLI. Radionuclides are retained in this organ initially at the rate of $0.004 \mathrm{~Bq} / \mathrm{hr}$ (between $0.5 \mathrm{hr}$ and $1^{\mathrm{st}} \mathrm{hr}$ of intake), attaining maximum at $12^{\text {th }} \mathrm{hr}$ after the start. The maximum value retained in the organ is around $0.419 \mathrm{~Bq}$ and it happens at around $24^{\text {th }} \mathrm{hr}$ after starting of the ingestion.

Fig. 2 shows the variation of absorbed dose by ST, SI, ULI and LLI for $1 \mathrm{yr}$ old child ingesting the radionuclide ${ }^{60} \mathrm{Co}$ in 0 to 48 hours. Absorbed dose in stomach decreases exponentially with time, its value becoming practically insignificant after a period of around 8 hours. Absorbed dose in SI, ULI and LLI increases exponentially and then decreases. This pattern of variation is expected mainly because of biological excretion phenomenon. Additionally the effect of radioactive half life is also active in these cases.

The maximum absorbed dose per unit intake of ${ }^{60} \mathrm{Co}$ are found to be $1.35 \times 10^{-10}, 3.20 \times 10^{-10}$ and $3.86 \mathrm{x}$ $10^{-10} \mathrm{mSv}$ for SI, ULI and LLI respectively. The maximum absorbed dose in ST occurs instantaneously at the moment of first intake. Similar results are found for age groups $10 \mathrm{yrs}$, adult female and adult male respectively (Figs. 3-5). Absorbed doses in different parts of

GI tract for male are found to be the lowest values because of relatively larger tissue mass. Absorbed doses for female are larger than that for male. The values increase with the decrease of ages. Variation of dose rates for different age groups is shown in Table 1. Once again taking the necessary data from all the figures variation of doses at different compartments of GI tract with variation of age group is displayed (Figs. 6 to 8). Committed equivalent doses have been calculated for the GI tract of each age group. The values thus obtained are shown in Table 2. 


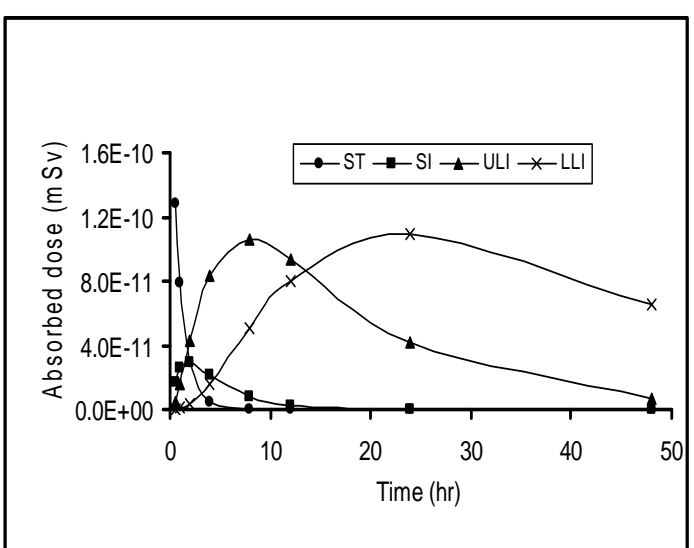

Fig. 3 Variation of absorbed dose due to ${ }^{60} \mathrm{Co}$ with time for $10 \mathrm{yrs}$ old subject

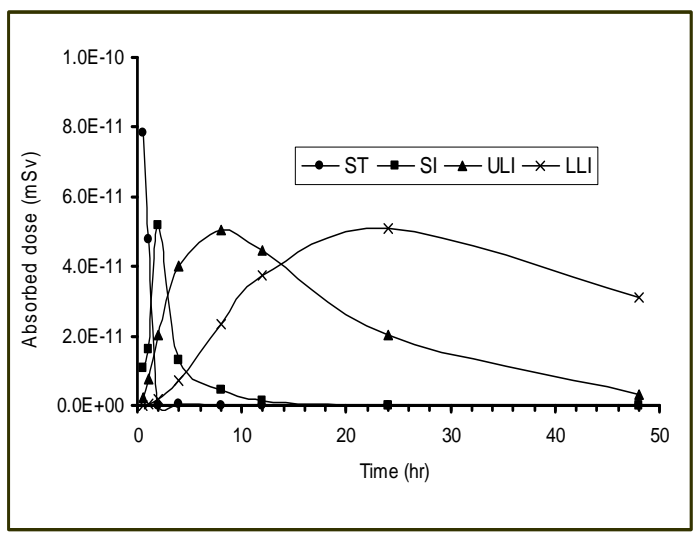

Fig. 5 Variation of absorbed dose due to ${ }^{60} \mathrm{Co}$ with time for Adult Male

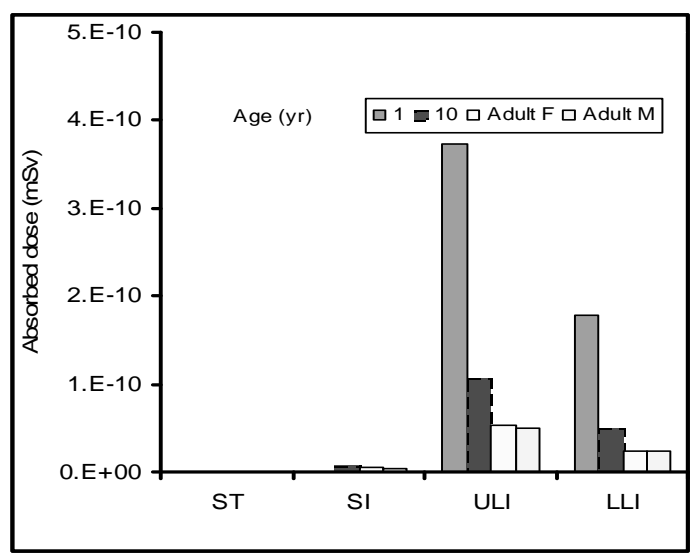

Fig. 7 Absorbed dose due to ${ }^{60} \mathrm{Co}$ at different compartments of GI tract after $8 \mathrm{hrs}$ of intake

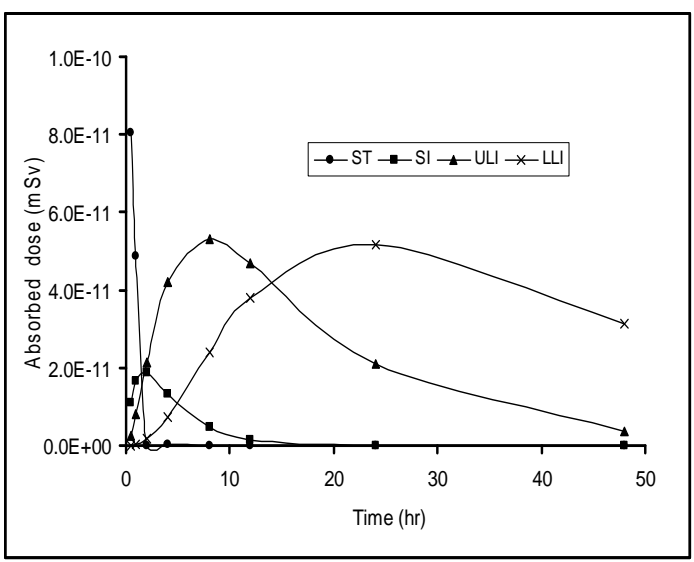

Fig. 4 Variation of absorbed dose due to ${ }^{60} \mathrm{Co}$ with time for Adult Female

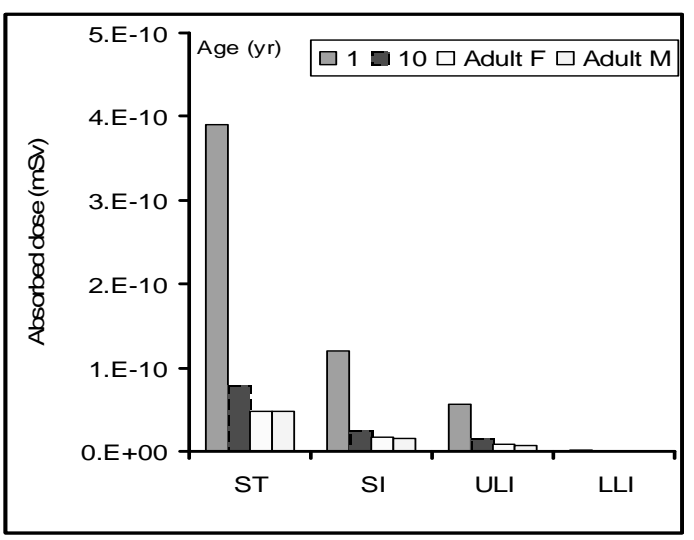

Fig. 6 Absorbed dose due to ${ }^{60} \mathrm{Co}$ at different compartments of GI tract after $1 \mathrm{hr}$ of intake

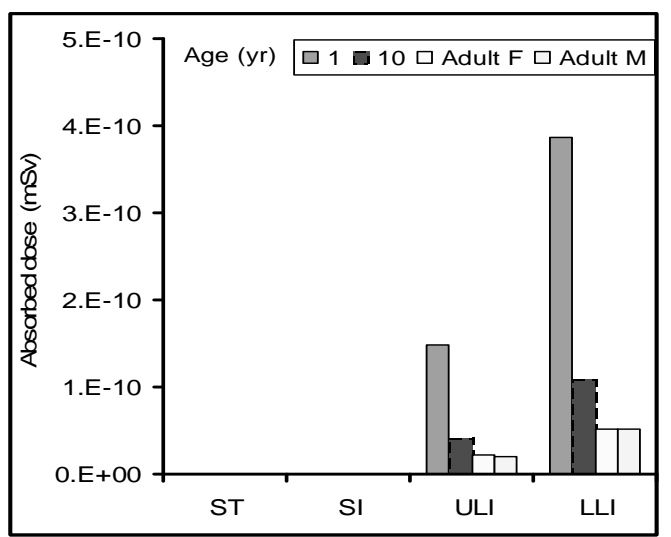

Fig. 8 Absorbed dose due to ${ }^{60} \mathrm{Co}$ at different compartments of GI tract after $24 \mathrm{hr}$ of intake

Table 1 Variation of dose rate measured $(\mathrm{mSv} / \mathrm{hr})$ in different compartments of GI tract due to ${ }^{60} \mathrm{Co}$ 


\begin{tabular}{|c|c|c|c|c|c|c|c|c|c|c|c|c|}
\hline \multirow{2}{*}{$\begin{array}{l}\text { Compart. } \\
\text { of GI } \\
\text { tract }\end{array}$} & \multicolumn{3}{|c|}{$1 \mathrm{yr}$} & \multicolumn{3}{|c|}{$10 \mathrm{yrs}$} & \multicolumn{3}{|c|}{ Adult Male } & \multicolumn{3}{|c|}{ Adult Female } \\
\hline & $\begin{array}{l}\text { Risin } \\
\text { g } \\
\text { Rate }\end{array}$ & $\begin{array}{l}\text { Fallin } \\
\text { g Rate }\end{array}$ & $\begin{array}{l}\text { Max. } \\
\text { Dose }\end{array}$ & $\begin{array}{l}\text { Risin } \\
\text { g } \\
\text { Rate }\end{array}$ & $\begin{array}{l}\text { Falling } \\
\text { Rate }\end{array}$ & $\begin{array}{l}\text { Max } \\
\text { Dos } \\
\text { e }\end{array}$ & $\begin{array}{l}\text { Risin } \\
\text { g } \\
\text { Rate }\end{array}$ & $\begin{array}{l}\text { Fallin } \\
\text { g } \\
\text { Rate }\end{array}$ & $\begin{array}{l}\text { Max. } \\
\text { Dose }\end{array}$ & $\begin{array}{l}\text { Risin } \\
\text { g } \\
\text { Rate }\end{array}$ & $\begin{array}{l}\text { Fallin } \\
\text { g } \\
\text { Rate }\end{array}$ & $\begin{array}{l}\text { Max. } \\
\text { Dose }\end{array}$ \\
\hline ST & NA & $\begin{array}{l}4.54 \mathrm{x} \\
10^{-10}\end{array}$ & * & NA & $\begin{array}{l}1.01 \quad \mathrm{x} \\
10^{-11}\end{array}$ & $*$ & NA & $\begin{array}{l}6.18 \\
x \\
10^{-11}\end{array}$ & * & NA & $\begin{array}{l}6.34 \\
x \\
10^{-11}\end{array}$ & $*$ \\
\hline SI & $\begin{array}{l}7.74 \times x \\
10^{-11}\end{array}$ & $\begin{array}{l}1.96 \mathrm{x} \\
10^{-11}\end{array}$ & $\begin{array}{l}1.35 \\
x \\
10^{-10}\end{array}$ & $\begin{array}{l}1.7 \mathrm{x} \\
10^{-12}\end{array}$ & $\begin{array}{l}3.3 \mathrm{x} \\
10^{-12}\end{array}$ & $\begin{array}{l}2.97 \\
x \\
10^{-11}\end{array}$ & $\begin{array}{l}1.04 \\
x \\
10^{-11}\end{array}$ & $\begin{array}{l}7.5 \mathrm{x} \\
10^{-12}\end{array}$ & $\begin{array}{l}1.81 \\
x \\
10^{-11}\end{array}$ & $\begin{array}{ll}1.08 \\
x & 10^{-} \\
11 & \end{array}$ & $\begin{array}{l}2.7 \times \\
10^{-12}\end{array}$ & $\begin{array}{l}1.87 \\
x \\
10^{-11}\end{array}$ \\
\hline ULI & $\begin{array}{l}7.66 \mathrm{x} \\
10^{-11}\end{array}$ & $\begin{array}{l}1.13 \mathrm{x} \\
10^{-12}\end{array}$ & $\begin{array}{l}3.74 \\
x \\
10^{-10}\end{array}$ & $\begin{array}{l}2.17 \\
\times 12 \\
12\end{array}$ & $\begin{array}{l}3.2 \mathrm{x} \\
10^{-12}\end{array}$ & $\begin{array}{l}1.06 \\
x \\
10^{-10}\end{array}$ & $\begin{array}{l}1.04 \\
x \\
10^{-11}\end{array}$ & $\begin{array}{ll}1.53 \\
\mathrm{x} & 10^{-} \\
12 & \end{array}$ & $\begin{array}{l}5.06 \\
x \\
10^{-11}\end{array}$ & $\begin{array}{l}1.10 \\
x \quad 10^{-} \\
11\end{array}$ & $\begin{array}{ll}1.63 \\
x & 10^{-} \\
12 & \end{array}$ & $\begin{array}{l}5.33 \\
x \\
10^{-11}\end{array}$ \\
\hline LLI & $\begin{array}{l}3.68 \mathrm{x} \\
10^{-12}\end{array}$ & $\begin{array}{l}6.33 \times x \\
10^{-12}\end{array}$ & $\begin{array}{l}3.86 \\
x \\
10^{-10}\end{array}$ & $\begin{array}{l}1.03 \\
\mathrm{x} \quad 10^{-} \\
12\end{array}$ & $\begin{array}{ll}1.8 & \mathrm{x} \\
10^{-12}\end{array}$ & $\begin{array}{l}1.09 \\
x \\
10^{-10}\end{array}$ & $\begin{array}{l}4.84 \\
x \\
10^{-13}\end{array}$ & $\begin{array}{l}8.3 \times \\
10^{-13}\end{array}$ & $\begin{array}{l}5.09 \\
x \\
10^{-11}\end{array}$ & $\begin{array}{l}4.9 \mathrm{x} \\
10^{-13}\end{array}$ & $\begin{array}{l}8.5 \mathrm{x} \\
10^{-13}\end{array}$ & $\begin{array}{l}5.18 \\
x \\
10^{-11}\end{array}$ \\
\hline
\end{tabular}

Compart.: Compartment, NA: Not Applicable

$*$ Calculations have been done considering $\mathrm{t}=0$ when stomach absorbs maximum dose.

Table 2 Committed equivalent dose $(\mathrm{mSv})$ due to intake of $1 \mathrm{~Bq}$ of ${ }^{60} \mathrm{Co}$

\begin{tabular}{|l|l|l|l|l|}
\hline $\begin{array}{l}\text { Parts of GI } \\
\text { tract }\end{array}$ & $1 \mathrm{yr}$ & $10 \mathrm{yrs}$ & Adult female & Adult male \\
\hline ST & $3.44 \times 10^{-6}$ & $7.72 \times 10^{-7}$ & $4.81 \times 10^{-7}$ & $4.7 \times 10^{-7}$ \\
\hline SI & $2.92 \times 10^{-6}$ & $6.41 \times 10^{-7}$ & $4.03 \times 10^{-7}$ & $3.92 \times 10^{-7}$ \\
\hline ULI & $2.96 \times 10^{-5}$ & $8.38 \times 10^{-6}$ & $4.21 \times 10^{-6}$ & $4 \times 10^{-6}$ \\
\hline LLI & $7.16 \times 10^{-5}$ & $2.01 \times 10^{-5}$ & $9.6 \times 10^{-6}$ & $9.44 \times 10^{-6}$ \\
\hline
\end{tabular}

The committed effective dose due to ${ }^{60} \mathrm{Co}$ in GI tract for age groups $1 \mathrm{yr}, 10 \mathrm{yrs}$, adult female and adult male are found to be $6.56 \times 10^{-6} \mathrm{mSv} / \mathrm{Bq}, 1.82 \times 10^{-6} \mathrm{mSv} / \mathrm{Bq}, 8.96 \times 10^{-7} \mathrm{mSv} / \mathrm{Bq}$ and $8.73 \times 10^{-7}$ $\mathrm{mSv} / \mathrm{Bq}$ respectively.

\section{CONCLUSION}

The present study describes a generic methodology for the calculation of internal radiation doses for Bangladeshi people due to acute intake of ${ }^{60} \mathrm{Co}$ through ingestion. The following important observations could be made from the study.

Retention values as observed in the work become insignificant after about $8 \mathrm{hrs}$ in ST, about $12 \mathrm{hrs}$ in SI and $48 \mathrm{hrs}$ in ULI for the radionuclide ${ }^{60} \mathrm{Co}$. But even after $48 \mathrm{hrs}$ a significant amount of radioactivity remains in LLI. The absorbed dose for children has been observed to be higher than that of others having higher body mass. This is justified, since absorbed dose is inversely proportional to the mass of the tissue compartment of GI tract. Regarding age the variation of absorbed dose, committed equivalent dose and committed effective dose follows the sequence: $1 \mathrm{yr}>10 \mathrm{yrs}>$ adult female $>$ adult male. Regarding compartment the trend of variation of absorbed dose after $1 \mathrm{hr}$ of ingestion is ST > SI > ULI > LLI. Regarding tissue compartments the variation pattern of committed equivalent dose is LLI > ULI > ST > SI for the radionuclide. The highest committed effective dose per unit intake for each radionuclide is found in the GI tract of $1 \mathrm{yr}$ old child. This value is $6.56 \times 10^{-6} \mathrm{mSv} / \mathrm{Bq}$ due to ingestion of ${ }^{60} \mathrm{Co}$. For other age groups these values are slightly smaller than those for $1 \mathrm{yr}$ old child. 
The purpose of this study is to provide persons charged with the responsibility for monitoring internal exposures of workers with comprehensive guidance on the methods for assessing committed effective doses from estimated intakes of radioactive material. However, in presenting the level of technical detail necessary for this purpose, this study will also be useful to those concerned with the planning and management of occupational monitoring program.

\section{References}

1. ICRP (International Commission on Radiological Protection), Report of the Task Group on Reference Man (ICRP Publication 23), Oxford, Pergamon Press, (1975).

2. Tipton, I.H., Cook, M.J., Weight of Total Gastrointestinal Tract and Its Subfractions. In: Health Physics Division Annual Progress Report for Period Ending July 31, 1969. Report ORNL-4446, Oak Ridge National Laboratory, Oak Ridge,TN, pp. 301-302, (1969).

3. Harrison, J.D., Ingested Radionuclides. In: Potten, C.S. \& Hendry, J.H., eds, Radiation and Gut, Amsterdam, Elsevier Science, pp. 253-289, (1995).

4. ICRP (International Commission on Radiological Protection), Limits for Intakes of Radionuclides by Workers: Part 1, Publication 30, Pergamon Press, Oxford and New York (1979).

5. ICRP (International Commission on Radiological Protection), Age-dependent Doses to Members of the Public from Intake of Radionuclides: Part 1, Publication 56, Pergamon Press, Oxford and New York (1989).

6. ICRP (International Commission on Radiological Protection), Age-dependent Doses to Members of the Public from Intake of Radionuclides: Part 4, Inhalation Dose Coefficients, Publication 71, Pergamon Press, Oxford and New York (1995).

7. Quddus A.H.M. R., Assessment of Internal Radiation Doses due to Intake of Radionuclides by Ingestion in Human Body, Ph. D. Thesis, 2010; pp 56-66.

8. Skrable K, French C, Chabot G and Major A, A general equation for the kinetics of linear first order phenomena and suggested applications. Health Phys; 27:155-157; (1974).

9. Food and Agriculture Organization of the United Nations, International Atomic Energy Agency, International Labour Organisation, OECD Nuclear Energy Agency, Pan American Health Organization, World Health Organization. International Basic Safety Standards for Protection against Ionizing Radiation and for the Safety of Radiation Sources. Safety Series 115, (1996). 